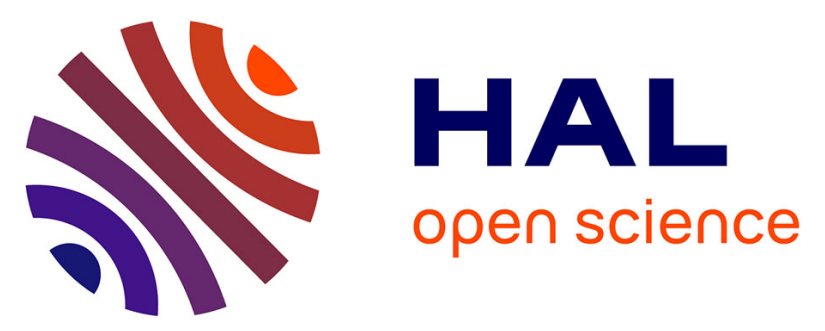

\title{
A new class of fluorescent chemosensors based on the $\mathrm{A}$ new class of fluorescent chemosensors based on the $\beta$-aminobisphosphonate receptor
}

John Callan, Sukanta Kamila, Narinder Singh, Ray Mulrooney, Martha Mackay, Maedhbh Cronin, John Dunn, David Durham

\section{To cite this version:}

John Callan, Sukanta Kamila, Narinder Singh, Ray Mulrooney, Martha Mackay, et al.. A new class of fluorescent chemosensors based on the A new class of fluorescent chemosensors based on the $\beta$-aminobisphosphonate receptor. Supramolecular Chemistry, 2009, 21 (07), pp.643-649. 10.1080/10610270802709352 . hal-00520015

\section{HAL Id: hal-00520015 https://hal.science/hal-00520015}

Submitted on 22 Sep 2010

HAL is a multi-disciplinary open access archive for the deposit and dissemination of scientific research documents, whether they are published or not. The documents may come from teaching and research institutions in France or abroad, or from public or private research centers.
L'archive ouverte pluridisciplinaire HAL, est destinée au dépôt et à la diffusion de documents scientifiques de niveau recherche, publiés ou non, émanant des établissements d'enseignement et de recherche français ou étrangers, des laboratoires publics ou privés. 


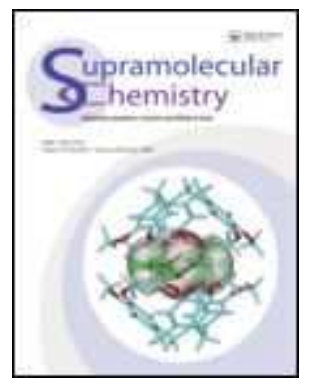

\section{A new class of fluorescent chemosensors based on the $A$ new class of fluorescent chemosensors based on the $\beta$ - aminobisphosphonate receptor}

\begin{tabular}{|r|l|}
\hline Journal: & Supramolecular Chemistry \\
\hline Manuscript ID: & GSCH-2008-0114.R3 \\
\hline Manuscript Type: & Full Paper \\
\hline Author: & 27-Nov-2008 \\
\hline & $\begin{array}{l}\text { Complete List of Authors: } \\
\text { Kamillan, John; Robert Gordon University } \\
\text { Sulrooney, Ray; RGU } \\
\text { MacKay, Martha; RGU } \\
\text { Cronin, Maedhbh; RGU } \\
\text { Dunn, John; RGU } \\
\text { Durham, David; RGU }\end{array}$ \\
\hline Keywords: & B-aminobisphosphonate, sensor, fluorescence \\
\hline
\end{tabular}

\section{今 ScholarONE" \\ Manuscript Central}




\section{Graphical Abstract}

A new class of fluorescent chemosensors based on the $\beta$-aminobisphosphonate receptor. John F. Callan ${ }^{1 *}$, Sukanta Kamila ${ }^{1}$, Ray C. Mulrooney ${ }^{1}$, Martha MacKay ${ }^{1}$, Maedhbh C. Cronin ${ }^{1}$, John Dunn ${ }^{1}$, and David G. Durham ${ }^{1}$.

School of Pharmacy and Life Sciences, The Robert Gordon University, Aberdeen, AB10 IFR, UK
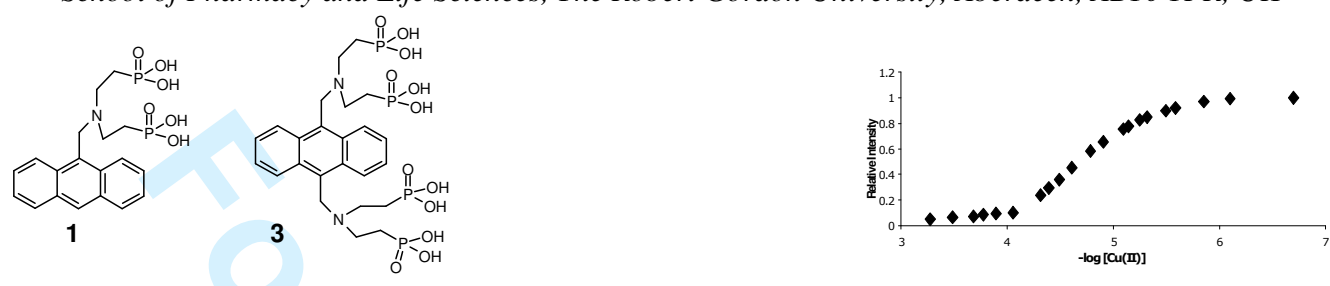


\title{
A new class of fluorescent chemosensors based on the $\beta$ - aminobisphosphonate receptor
}

\author{
John F. Callan, ${ }^{\text {a }}$ Sukanta Kamila, ${ }^{\text {a }}$ Narinder Singh, ${ }^{\text {a }}$ Ray C. Mulrooney, ${ }^{\text {a Martha }}$

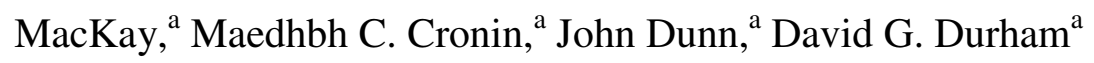 \\ ${ }^{\text {a }}$ School of Pharmacy and Life Sciences, The Robert Gordon University, Aberdeen, \\ AB10 1FR,UK \\ * corresponding author E Mail .j.callan@rgu.ac.uk Ph: +44(0)1224 262546, Fax: \\ $+44(0) 1224262555$
}

\begin{abstract}
The photophysical properties of a range of fluorescent sensors with $\beta$ aminobisphosphonate receptors have been studied. The compounds were designed according to the Fluorophore-Spacer-Receptor format of Photoinduced Electron Transfer (PET) based sensors. The sensors displayed unusual fluorescence intensity$\mathrm{pH}$ profiles that was attributed to a receptor - fluorophore H-bonding interaction that resulted in a quenching of fluorescence. The number of receptors and the nature of the fluorophore were both shown to have an effect on the $\mathrm{pH}$ profiles of the sensors. In addition, compound $\mathbf{1}$ was also shown to be selective for $\mathrm{Cu}^{2+}$ ions, in water at $\mathrm{pH} 7.4$ with sensitivity in the $\mu \mathrm{M}$ range.
\end{abstract}

Keywords: Flourescence, sensor, pH, copper. 


\section{Introduction}

$\beta$-aminobisphosphonate derivatives, such as pamidronate (Aredia), are commercially used to treat bone resorption disorders such as osteoporosis and Pagets disease. ${ }^{1}$ Their activity is thought to be due to the ability to strongly chelate certain metal ions, particularly $\mathrm{Ca}^{2+} \cdot 2$ In addition, it has been demonstrated using electron paramagnetic spectroscopy that $\beta$-aminobisphosphonates derivatives bind strongly to $\mathrm{Cu}^{2+3}$. Therefore, their incorporation as the ionophore component of luminescent sensing assemblies seems a logical progression.

We have previously developed a luminescent sensor that incorporated $\beta$ aminobisphosphonate as a receptor component. ${ }^{4}$ The sensor, designed according to the Fluorophore-Spacer-Receptor format of Photoinduced Electron Transfer (PET) based sensors, ${ }^{5}$ was shown to selectively bind $\mathrm{Cu}^{2+}$ ions in water at $\mathrm{pH}$ 7.4. However, the choice of naphthalene as fluorophore has obvious restrictions when considering intracellular applications, as UV excitation is necessary. Here, we improve on the design using anthracene as fluorophore by preparing \{2-[anthracen-9-ylmethyl-(2phosphono-ethyl)-amino]-ethyl $\}$-phosphonic acid (1) and $\quad\{2-[(10-\{[$ Bis- $(2-$ phosphono-ethyl)-amino]-methyl \}-anthracen-9-ylmethyl)-(2-phosphono-ethyl)amino]-ethyl -phosphonic acid (3). Both sensors were again constructed according to the PET design principle and differ only by the number of receptor ligands they possess. Control compounds were also prepared ( 2 and $\mathbf{4}$ ) in which the phosphonate receptors were absent. The preparation of these compounds has enabled us to propose a mechanism for the unusual $\mathrm{pH}$ profile of the sensors $\mathbf{1}$ and $\mathbf{3}$. In particular, it has allowed us to correct upon a postulated mechanism for the $\mathrm{pH}$ behavior of the aforementioned naphthalene based compound from an earlier communication. ${ }^{4}$ The 
selectivity and sensitivity of $\mathbf{1}$ and $\mathbf{3}$ was also established against a range of common metal ions to determine their potential use as chemosensors.

\section{Experimental}

\section{General}

All reagents used were of the highest grade obtainable and were purchased from Aldrich. The compounds 5, 7-8 and 10 were prepared with literature methods. ${ }^{4,13,15}$ Absorbance measurements were recorded on an Agilent UV-Vis spectrometer using $10 \mathrm{~mm}$ quartz cuvettes. Fluorescence measurements were recorded on a Shimadzu RF-5301 luminescence spectrometer using $10 \mathrm{~mm}$ quartz cuvettes. Excitation slit size was $10 \mathrm{~nm}$ and emission slit size was $10 \mathrm{~nm}$. Scan speed was set at 500. NMR spectra were recorded on a Bruker AVANCE $400 \mathrm{MHz}$ spectrometer. Chemical shifts are reported in parts per million, downfield of TMS. Details of solvents are provided in the figure captions. Low resolution MS were obtained on an Agilent 6130 Quadropole LC/MS system. Accurate Mass data was provided by the EPSRC National Mass Spectrometry Service, UK. Figure 3 was prepared on ArgusLab 4.0. The antrhracene aminobisphosphonate was energy minimized and the binding site optimized by rotation of the side chains.

Synthesis of (2-\{anthracen-9-ylmethyl-[2-(diethoxy-phosphoryl)-ethyl]-amino\}ethyl)- phosphonic acid diethyl ester (6)

A mixture of 9-(aminomethyl)anthracene $(0.97 \mathrm{~g}, 4.72 \mathrm{mmol})$ and diethyl vinylphosphonate $(4.42 \mathrm{~mL}, 28.3 \mathrm{mmol})$ was heated at reflux in dry methanol $(20 \mathrm{~mL})$ for 10 days. Following cooling of the reaction mixture the solvent was removed under 
reduced pressure. The crude product was purified by flash chromatography using silica gel eluted with methanol : dichloromethane (1:50). The product was separated as an orange liquid $(0.29 \mathrm{~g}, 11 \%) ; \delta_{\mathrm{H}}\left(400 \mathrm{MHz}, \mathrm{DMS} 0-d_{6}\right) 1.08(12 \mathrm{H}, \mathrm{t}, J 6.4 \mathrm{~Hz},-$ $\left.\mathrm{OCH}_{2} \mathrm{CH}_{3}\right), 1.95\left(4 \mathrm{H}, \mathrm{m},-\mathrm{CH}_{2} \mathrm{CH}_{2} \mathrm{P}(\mathrm{O})\left(\mathrm{OEt}_{2}\right)_{2}\right), 2.81\left(4 \mathrm{H}, \mathrm{m},-\mathrm{NCH}_{2} \mathrm{CH}_{2}-\right), 3.85(8 \mathrm{H}$, m, $\left.-\mathrm{OCH}_{2} \mathrm{CH}_{3}\right), 4.59\left(2 \mathrm{H}, \mathrm{s},-\mathrm{CH}_{2} \mathrm{~N}-\right) 7.56(4 \mathrm{H}, \mathrm{m}, \mathrm{Ar}-\mathrm{H}) 8.09(2 \mathrm{H}, \mathrm{d}, J 8.0 \mathrm{~Hz}, \mathrm{Ar}-$ H), $8.55(3 \mathrm{H}, \mathrm{m}, \mathrm{Ar}-\mathrm{H}) ; \delta_{\mathrm{c}}\left(100 \mathrm{MHz}, \mathrm{DMS} 0-d_{6}\right) 16.0,21.4,22.76,45.7,49.2,123.4$, $123.9,125.0,127.1,129.2,130.3,130.9,134.5 ; \mathrm{m} / \mathrm{z}(\mathrm{ESMS}) 536(60 \%)\left[\mathrm{M}^{+}\right]$ 400 (100\%), 191 (24\%); HRMS calcd for $\mathrm{C}_{27} \mathrm{H}_{39} \mathrm{NO}_{6} \mathrm{P}_{2}$ 536.2325; found 536.2322.

\section{Synthesis of $\quad$ 22-[anthracen-9-ylmethyl-(2-phosphono-ethyl)-amino]-ethyl\}- phosphonic acid (1)}

To a solution of $6(0.12 \mathrm{~g}, 0.23 \mathrm{mmol})$ in dry $\mathrm{CH}_{2} \mathrm{Cl}_{2}(10 \mathrm{~mL})$ was added bromotrimethylsilane $(0.82 \mathrm{~mL}, 6.31 \mathrm{mmol})$. The mixture was stirred overnight at room temperature. Evaporation of the solvent along with excess bromotrimethylsilane under reduced pressure afforded the crude product which was triturated with hexane. The resulting solid was dissolved in DCM and the product obtained after precipitation with ether $(0.092 \mathrm{~g}, 98 \%)$; mp $172^{\circ} \mathrm{C} ; \delta_{\mathrm{H}}(400 \mathrm{MHz}, \mathrm{MeOD}) 2.1(4 \mathrm{H}, \mathrm{m},-$ $\left.\mathrm{CH}_{2} \mathrm{CH}_{2} \mathrm{P}(\mathrm{O})(\mathrm{OH})_{2}\right), 3.6\left(4 \mathrm{H}, \mathrm{m},-\mathrm{NCH}_{2} \mathrm{CH}_{2}-\right), 5.5\left(2 \mathrm{H}, \mathrm{s},-\mathrm{CH}_{2} \mathrm{~N}-\right) 7.65(4 \mathrm{H}, \mathrm{m}, \mathrm{Ar}-$ H), $8.2(2 \mathrm{H}, \mathrm{d}, J 8.0 \mathrm{~Hz}, \mathrm{Ar}-\mathrm{H}), 8.45(2 \mathrm{H}, \mathrm{d}, J 8 \mathrm{~Hz}, \mathrm{Ar}-\mathrm{H}), 8.85$ (1H, s, Ar-H); $\delta \mathrm{c}(100 \mathrm{MHz}, \mathrm{MeOD}) 22.7,24.2,51.8,120.7,124.0,126.8,129.4,129.6,130.9,132.8$, 133.0; m/z (ESMS) $423(25 \%)\left[\mathrm{M}^{+}\right], 232(50 \%), 121(100 \%)$; HRMS calcd for $\mathrm{C}_{19} \mathrm{H}_{23} \mathrm{NO}_{6} \mathrm{P}_{2}(\mathrm{M}-\mathrm{H})^{-}$422.0928; found 422.0923.

\section{Synthesis of anthracen-9-ylmethyl-diethyl-amine (2)}

A mixture of 9-(chloromethyl)anthracene $(1.080 \mathrm{~g}, 4.41 \mathrm{mmol})$, diethylamine $(1.37$ $\mathrm{mL}, 13.23 \mathrm{mmol})$ and DIPEA $(2.3 \mathrm{~mL}, 13.23 \mathrm{mmol})$ in anhydrous 1,4 dioxane (10 
mL) was stirred at $100{ }^{\circ} \mathrm{C}$ overnight. The solution was allowed to cool and excess solvent and un-reacted amine were removed by evaporation under reduced pressure. The crude product was then washed with distilled water and extracted with ethyl acetate. The organic layer was dried over $\mathrm{Na}_{2} \mathrm{SO}_{4}$ and the solvent removed under reduced pressure to afford the product $(0.89 \mathrm{~g}, 82.54 \%) ; \mathrm{mp} 84^{\circ} \mathrm{C} ; \delta_{\mathrm{H}}(400 \mathrm{MHz}$, $\left.\mathrm{CDCl}_{3}\right) 1.00\left(6 \mathrm{H}, \mathrm{t}, J 6.5 \mathrm{~Hz},-\mathrm{NCH}_{2} \mathrm{CH}_{3}\right), 2.55\left(4 \mathrm{H}, \mathrm{q}, J 7.0 \mathrm{~Hz},-\mathrm{NCH}_{2} \mathrm{CH}_{3}\right), 4.45$ (2H, s, $\left.-\mathrm{CH}_{2} \mathrm{NCH}_{2} \mathrm{CH}_{3}\right), 7.45(4 \mathrm{H}, \mathrm{m}, \mathrm{Ar}-\mathrm{H}), 7.9(2 \mathrm{H}, \mathrm{d}, J 8.5 \mathrm{~Hz}, \mathrm{Ar}-\mathrm{H}), 8.30(1 \mathrm{H}, \mathrm{s}$, Ar-H), $8.50(2 \mathrm{H}, \mathrm{d}, J 8.0 \mathrm{~Hz}, \mathrm{Ar}-\mathrm{H}) ; \delta_{\mathrm{C}}\left(100 \mathrm{MHz}, \mathrm{CDCl}_{3}\right)$ 10.9, 45.6, 49.2, 122.8, 123.9, 124.6, 126.4, 127.9, 130.4, 132.4, 132.9; m/z (ESMS) $264(10 \%)\left(\mathrm{M}^{+}\right), 191$ (100\%); HRMS calcd for $\mathrm{C}_{19} \mathrm{H}_{21} \mathrm{~N} 264.1747$; found 264.1750.

Synthesis of $\quad(2-\{[10-(\{$ Bis-[2-(diethoxy-phosphoryl)-ethyl]-amino\}-methyl)anthracen-9-ylmethyl]-[2-(diethoxy-phosphoryl)-ethyl]-amino\}-ethyl)phosphonic acid diethyl ester (9)

The procedure for the preparation of $\mathbf{6}$ was followed using the following amounts of reagents: $8(1 \mathrm{~g}, 4.23 \mathrm{mmol})$ and diethylvinyl phosphonate $(8.58 \mathrm{~mL}, 55.0 \mathrm{mmoL})$. The product was obtained as an orange solid $(0.54 \mathrm{~g}, 16.7 \%) ; \mathrm{mp} 115^{\circ} \mathrm{C} ; \delta_{\mathrm{H}}(400 \mathrm{MHz}$, MeOD) $1.05\left(24 \mathrm{H}, \mathrm{m}, 8 \mathrm{x}-\mathrm{CH}_{3}\right), 1.87\left(8 \mathrm{H}, \mathrm{m}, 4 \mathrm{x}-\mathrm{CH}_{2} \mathrm{P}-\right), 2.76\left(8 \mathrm{H}, \mathrm{m}, 4 \mathrm{x}-\mathrm{NCH}_{2}-\right)$, $3.70\left(16 \mathrm{H}, \mathrm{m}, 8 \mathrm{x}-\mathrm{OCH}_{2^{-}}\right), 4.51\left(4 \mathrm{H}, \mathrm{s}, 2 \mathrm{x} \mathrm{Ar}-\mathrm{CH}_{2}\right), 7.42\left(4 \mathrm{H}, \mathrm{dd}, J_{1} 3.5 \mathrm{~Hz}, J_{2} 8.0 \mathrm{~Hz}\right.$ Ar-H), 8.47(4H, dd, $\left.J_{1} 3.5 \mathrm{~Hz}, J_{2} 3.0 \mathrm{~Hz}, \mathrm{Ar}-\mathrm{H}\right) ; \delta_{\mathrm{C}}(100 \mathrm{MHz}, \mathrm{MeOD}) 16.6,22.9$, 24.3, 46.8, 51.2, 126.6, 127.9, 131.6, 132.4; m/z (ESMS) $894(5 \%)\left[\mathrm{M}^{+}\right], 548(10 \%)$, $447(100 \%)\left[\mathrm{M}^{2+}\right], 346$ (15\%); HRMS calcd for $\mathrm{C}_{40} \mathrm{H}_{68} \mathrm{~N}_{2} \mathrm{O}_{12} \mathrm{P}_{4}$ 893.3795; found 893.3810. 
Synthesis of $\quad\{2-[(10-\{[$ Bis-(2-phosphono-ethyl)-amino]-methyl $\}$-anthracen-9ylmethyl)-(2-phosphono-ethyl)-amino]-ethyl\}-phosphonic acid (3)

The procedure for the preparation of $\mathbf{1}$ was followed using the following amounts of reagents: 9 (0.54 g, $0.60 \mathrm{mmol})$ and bromotrimethylsilane $(1.26 \mathrm{~mL}, 9.60 \mathrm{mmol})$. The product was obtained as an orange solid $(0.12 \mathrm{~g}, 30 \%) . \delta_{\mathrm{H}}(400 \mathrm{MHz}, \mathrm{MeOD}) 2.00(8 \mathrm{H}$, m, 4x-CH $\left.\mathrm{CH}_{2} \mathrm{P}-\right), 3.30\left(8 \mathrm{H}, \mathrm{t}, 4 \mathrm{x}-\mathrm{NCH}_{2}-\right), 5.67\left(4 \mathrm{H}, \mathrm{s}, 2 \mathrm{x} \mathrm{Ar}-\mathrm{CH}_{2}\right), 7.77\left(4 \mathrm{H}, \mathrm{dd}, J_{1} 3.0\right.$ $\left.\mathrm{Hz}, J_{2} 7.5 \mathrm{~Hz}, \mathrm{Ar}-\mathrm{H}\right), 8.48\left(4 \mathrm{H}, \mathrm{dd}, J_{1} 3.0 \mathrm{~Hz}, J_{2} 7.5 \mathrm{~Hz}, \mathrm{Ar}-\mathrm{H}\right) ; \delta_{\mathrm{C}}(100 \mathrm{MHz}, \mathrm{MeOD})$ 20.8, 22.2, 48.1, 123.6, 123.8, 127.7, 130.5; m/z (ESMS) $668(20 \%)\left[\mathrm{M}^{+}\right], 588(60 \%)$ 560 (60\%), 349 (100\%); HRMS calcd for $\mathrm{C}_{24} \mathrm{H}_{36} \mathrm{~N}_{2} \mathrm{O}_{12} \mathrm{P}_{4}(\mathrm{M}-\mathrm{H})^{-} 667.1146$; found 667.1139.

\section{Synthesis of (10-Diethylaminomethyl-anthracen-9-ylmethyl)-diethyl-amine (4)}

The procedure for the preparation of $\mathbf{2}$ was followed using the following amounts of reagents: $7(1.00 \mathrm{~g}, 2.75 \mathrm{mmol})$, diethyl amine $(1.72 \mathrm{ml}, 16.54 \mathrm{mmol})$ and $\mathrm{N}$ ethyldiisopropylamine $(2.88 \mathrm{ml}, 16.54 \mathrm{mmol})$. The product was obtained as an orange solid $(0.72 \mathrm{~g}, 75.2 \%) . \mathrm{mp} 227^{\circ} \mathrm{C} ; \quad \delta_{\mathrm{H}}(400 \mathrm{MHz}, \mathrm{DMSO}) 1.23\left(12 \mathrm{H}, \mathrm{t}, 4 \mathrm{x}-\mathrm{CH}_{3}\right), 3.05$ (4H, m, 2x-NCH $\left.2_{2}^{-}\right), 3.29\left(4 \mathrm{H}, \mathrm{m}, 2 \mathrm{x}-\mathrm{NCH}_{2}-\right), 5.47\left(4 \mathrm{H}, \mathrm{s}, 2 \mathrm{x} \mathrm{Ar}-\mathrm{CH}_{2}\right), 7.77(4 \mathrm{H}, \mathrm{m}$, Ar-H), 8.54 (4H, m, Ar-H); $\delta_{\mathrm{C}}(100 \mathrm{MHz}, \mathrm{DMSO}) 8.7,47.2,48.4,125.3,125.5,127.4$, 130.9; m/z (ESMS): $276(100 \%), 204(6 \%), 175(11 \%)\left[\mathrm{M}^{2+}\right]$. HRMS calcd for $\mathrm{C}_{24} \mathrm{H}_{32} \mathrm{~N}_{2}$ 349.2638; found 349.2634.

\section{Synthesis of Diethyl-naphthalen-1-ylmethyl-amine (11)}

The procedure for the preparation of $\mathbf{2}$ was followed using the following amounts of reagents: 1-(chloromethyl)napthalene $(2.22 \mathrm{~mL}, 14.15 \mathrm{mmol})$, diethyl amine $(4.40 \mathrm{~mL}$, $42.45 \mathrm{mmol})$ and N-ethyldiisopropylamine $(7.39 \mathrm{~mL}, 42.46 \mathrm{mmol})$. The product was 
obtained as dark viscous liquid $(2.61 \mathrm{~g}, 84.2 \%) ; \delta_{\mathrm{H}}\left(400 \mathrm{MHz}, \mathrm{CDCl}_{3}\right) 0.99(6 \mathrm{H}, \mathrm{t}, \mathrm{J}$ 6.2Hz, 2 x- $\left.\mathrm{CH}_{3}\right), 2.49\left(4 \mathrm{H}, \mathrm{m}, 2 \mathrm{x}-\mathrm{NCH}_{2}-\right), 3.90\left(2 \mathrm{H}, \mathrm{s}, \mathrm{Ar}-\mathrm{CH}_{2^{-}}\right), 7.31(4 \mathrm{H}, \mathrm{m}, \mathrm{Ar}-\mathrm{H})$, $7.50(1 \mathrm{H}, \mathrm{d}, J 7.5 \mathrm{~Hz}, \mathrm{Ar}-\mathrm{H}), 7.66(1 \mathrm{H}, \mathrm{d}, J 7.5 \mathrm{~Hz}, \mathrm{Ar}-\mathrm{H}) .7 .72(1 \mathrm{H}, \mathrm{d}, J 7.5 \mathrm{~Hz}, \mathrm{Ar}-\mathrm{H})$; $\delta_{\mathrm{C}}\left(100 \mathrm{MHz}, \mathrm{CDCl}_{3}\right) 11.8,47.0,56.3,124.8,125.6,125.9,127.4,127.6,127.8,128.6$, 132.7, 134.0, 135.9; m/z (ESMS) $214(100 \%)\left[\mathrm{M}^{+}\right], 141$ (25\%); HRMS calcd for $\mathrm{C}_{15} \mathrm{H}_{19} \mathrm{~N} 214.1590$; found 214.1591.

\section{Results and Discussion}

\section{Synthesis of Sensors (1 and 3) and Control Compounds (2 and 4).}

The synthesis of the target and control compounds are shown in Scheme 1. Compound $\mathbf{1}$ was formed by first converting 9-chloromethylanthracene to 9aminomethyl anthracene (5) using the Delepine reaction. ${ }^{6}$ Following the Michael addition of 5 with diethylvinyl phosphonate and subsequent hydrolysis with bromotrimethylsilane, sensor $\mathbf{1}$ was isolated as a white solid. Control compound $\mathbf{2}$ was also formed from chloromethyl anthracene by direct reaction with diethyl amine.

A similar strategy was followed for the preparation of compound $\mathbf{3}$. Bisbromomethyl anthracene (7) was obtained from anthracene after reaction with hydrobromic acid. This was then converted to $\mathbf{3}$ following similar chemistry as outlined above. The control compound 4 was also formed from 9,10-bisbromomethyl anthracene by reaction with diethyl amine.

\section{pH titration of 1 and 2.}

UV analysis of both compounds showed characteristic anthracene absorbance with a $\lambda_{\text {MAX }}$ centered at $\sim 370 \mathrm{~nm}$. The emission spectra, when excited at $370 \mathrm{~nm}$, were also 
characteristic of anthracene based compounds, with three distinct bands observed at $401 \mathrm{~nm}, 422 \mathrm{~nm}$ and $444 \mathrm{~nm}$. However, the dependence of their emission on solution $\mathrm{pH}$ was markedly different. A plot of fluorescent intensity against $\mathrm{pH}$ is shown in Figure 1. The sigmoidal profile of control compound $2(\phi=0.16)$ was typical of a PET sensor with a tertiary amine as receptor, with fluorescence switching "On" over two log units. ${ }^{7}$ The emission intensity was low at high $\mathrm{pH}$ due to PET from the tertiary amine to the anthracene fluorophore. As $\mathrm{pH}$ was lowered, the tertiary amine became protonated, its oxidation potential raised and PET cancelled, allowing fluorescence to "Switch On". ${ }^{8}$ Using a plot of $-\log \left(F_{M A X}-F\right) /\left(F-F_{M I N}\right)$ against pH (where $\mathrm{F}_{\mathrm{MAX}}$ is the maximum fluorescence intensity, $\mathrm{F}_{\mathrm{MIN}}$ the minimum fluorescence intensity and $\mathrm{F}$ the measured fluorescence intensity) the pKa of the tertiary amine was calculated as $9.43 .^{9}$

The $\mathrm{pH}$ titration of sensor $\mathbf{1}(\phi=0.22)$ also switches "On" fully at $\mathrm{pH} 9(\mathrm{pKa}=10.24)$ but then the intensity falls off between $\mathrm{pH} 8-5$. This initial switching "On" can again be attributed to protonation of the tertiary amine canceling PET as in the case of the control, the pKa value being consistent with that found for the amino group in alkyl aminobisphosphonates determined by potentiometric titration ${ }^{3}$.

The reduction in fluorescence intensity between $\mathrm{pH}$ 's 8 - 5 can be explained by protonation of the phosphonate oxyanions and their hydrogen bonding with the $\pi-$ electron cloud of the anthracene. The intramolecular quenching of anthracene emission by carboxylic acid groups has been demonstrated before. ${ }^{7,10}$ The flexibility of the receptor unit in $\mathbf{1}$, means that the approach of the phosphonic acid group with the anthracene $\pi$-cloud is also feasible for $\mathbf{1}$. The slight rise and then fall in 
fluorescence intensity between $\mathrm{pH} 5-2$, is probably due to the stepwise protonation of the phosphonate groups before they interact with the anthracene $\pi$-system.

\section{pH titration of 3 and 4}

Figure 2 shows a plot of fluorescence intensity against $\mathrm{pH}$ for compounds $\mathbf{3}$ and $\mathbf{4}$. The control compound shows a typical sigmoidal profile with fluorescence switching "On" over two log units. Both tertiary amines must be protonated before fluorescence switches "On" as there are two PET channels present in the molecule. The calculated pKa of 8.34 of $4(\phi=0.12)$ is approximately one log unit lower than in $\mathbf{2}$. Again, the profile of sensor $3(\phi=0.09)$ is markedly different than that of the control. The fluorescence remains low until approximately $\mathrm{pH} 4$ when it switches "On" dramatically. There is also evidence of a small rise in intensity from $\sim \mathrm{pH}$ 's 12 - 9 (pKa 8.34) which falls off between pH's $9-7$. This can again be explained as in the case of $\mathbf{1}$, with the rise due to protonation of the tertiary amine, and the fall off due to oxyanion protonation and subsequent hydrogen bonding with the anthracene $\pi$-cloud. The much more effective quenching of fluorescence for $\mathbf{3}$ compared to $\mathbf{1}$ is most likely due to a stronger interaction between the protonated oxyanions and the anthracene $\pi$-cloud, due to the presence of the second receptor ligand. A second small step is also evident between $\mathrm{pH}$ 's 7 and $5(\mathrm{pKa}=5.99)$ which again may be explained by a stepwise protonation of the phosphonate groups before interaction with the anthracene $\pi$-cloud. But what causes the large enhancement in fluorescence on going from $\mathrm{pH}$ 's 4 - 2? The hydrogen bonding effect of the phosphonate groups with the anthracene $\pi$-cloud must be turned off in some manner.

We believe this can be best explained as follows: the full protonation of the phosphonate groups, coupled with the flexibility of the receptor units enables a strong 
hydrogen bonding interaction of the phosphonate groups with each other. That is, the phosphonate groups on one side of the anthracene molecule (the 9-position) interact strongly with those on the opposite side of the molecule (the 10-position) by bending to one side of the $\pi$-system, as depicted Figure 3. This strong hydrogen bonding interaction is at the expense of the hydrogen bonding with the anthracene $\pi$-cloud and enables fluorescence to switch "On". However, as observed in Figure 2, the intensity maxima of the sensor is somewhat smaller than in the control, indicating that a residual phosphonate - anthracene $\pi$-cloud quenching interaction still exists, even at $\mathrm{pH} 1.0$.

The mechanistic interpretation outlined above for the unusual $\mathrm{pH}$ profile of compounds $\mathbf{1}$ and $\mathbf{3}$ is different to that previously postulated by us in an earlier communication. For purposes of clarity we include the fluorescent intensity - pH profile for \{2-naphthalen-1-ylmethyl-(2-phosphono-ethyl)amino] ethyl\}-phosphonic acid (10) used in that study along with its control analogue (11) in Figure 4. The profile of $\mathbf{1 0}$ is similar to $\mathbf{1}$ in that it switches "On" at high pH, switches "Off" slightly at intermediate $\mathrm{pH}$ and then back "On" at low $\mathrm{pH}$. However, the magnitude of the decrease in intensity at intermediate $\mathrm{pH}$ is much smaller for $\mathbf{1 0}$ than for $\mathbf{1}$. In addition, the intensity of $\mathbf{1 0}$ at low $\mathrm{pH}(\mathrm{i} . \mathrm{e} \mathrm{pH}$ 2) is about that of its control $\mathbf{1 1}$ (i.e it is fully switched "On") while the intensity of $\mathbf{1}$ at the same $\mathrm{pH}$ is about half that of the control. We previously accounted for the intensity increase of $\mathbf{1 0}$ from pH's $12-10$ as being due to intramolecular proton transfer from a protonated phosphonate group to the tertiary amine of the receptor, resulting in a partial cancellation of the PET process. The second stepped increase in intensity from pH's 6 - 4 was attributed due to full protonation of the tertiary amine and a complete cancellation of the PET process. We now consider this to be an inaccurate description for the profile of $\mathbf{1 0}$ and believe the 
same reasons as offered for $\mathbf{1}$ and $\mathbf{3}$ are also evident for $\mathbf{1 0}$. That the reduction in intensity between pH's $9-7$ is much less dramatic for $\mathbf{1 0}$ than $\mathbf{1}$ is most likely due to the much smaller $\pi$-cloud of naphthalene compared to anthracene, leading to a reduced effectiveness of the phosphonate $-\pi$-cloud hydrogen bonding interaction and a reduced quench.

\section{Selectivity and Sensitivity measurements of 1 and 3}

The nature of the $\mathrm{pH}$ - fluorescence profile of $\mathbf{1}$ means that its use as an Off-On sensor for physiologically relevant analytes is limited, as its fluorescence remains "On" over a wide $\mathrm{pH}$ range. However, as the fluorescence intensity is quite high at $\mathrm{pH} 7.4, \mathbf{1}$ may be effective as an "On - Off" sensor in buffered solution. We screened $\mathbf{1}$ against a range of common metal ions, in 0.01 M HEPES buffer at $\mathrm{pH}$ 7.4. As shown in Figure 5 , addition of $\mathrm{Cu}^{2+}$ leads to an $\sim 80 \%$ quenching of the original fluorescent intensity, while $\mathrm{Fe}^{2+}$ and $\mathrm{Zn}^{2+}$ led to quenches of $\sim 60$ and $\sim 20 \%$ respectively, with the other ions having virtually no effect. The quenching effect of $\mathrm{Cu}^{2+}$ is expected as the open shell ion is known to quench fluorescence by electron and / or energy transfer. ${ }^{5 e}$ Also, its position in the Irving Williams series means it is a strong binder to ligands, irrespective of the nature or number of ligands involved. ${ }^{11}$ The quenching effect from $\mathrm{Fe}^{2+}$ is most likely due to an inner filter effect, ${ }^{12}$ but the quenching effect from the closed shell $\mathrm{Zn}^{2+}$, although minor, was not expected. In contrast, the addition of these ions to a solution of the control produced negligible quenching, highlighting the requirement of the aminobisphosphonate receptor for analyte binding. Figure 6 shows a plot of relative intensity against $-\log$ [anion] for $\mathrm{Cu}^{2+}$ and $\mathrm{Fe}^{2+}$. Both ions quench fluorescence over two log units indicating a 1:1 binding between sensor and 
metal ion. ${ }^{13}$ The binding constants, $\log \beta$, calculated from equation 1 were 4.72 and 5.23 for $\mathrm{Cu}^{2+}$ and $\mathrm{Fe}^{2+}$ respectively. ${ }^{9}$

$-\log \left(\mathrm{F}_{\mathrm{MAX}}-\mathrm{F}\right) /\left(\mathrm{F}-\mathrm{F}_{\mathrm{MIN}}\right)=\log [$ Anion $]+\log \beta \quad(1)$

This confirms that $\mathrm{Fe}^{2+}$ binds stronger to the sensor than $\mathrm{Cu}^{2+}$ as observed for $\mathbf{1 0}$ in a previous study ${ }^{4}$. The sensitivity of $\mathbf{1}$ for $\mathrm{Cu}^{2+}$ is in the physiologically relevant range ${ }^{14}$ and the quenching effect caused by $\mathrm{Fe}^{2+}$ can be cancelled by the addition of fluoride ion to produce the colorless $\mathrm{FeF}_{6}{ }^{3-} \cdot{ }^{12}$ Therefore, $\mathbf{1}$ could be utilized as a water soluble sensor for $\mathrm{Cu}^{2+}$, operable in the physiological range. The low fluorescence intensity of 3 at pH 7.4 means it is potentially suitable as an "Off - On" sensor, provided analyte binding is sufficient to disrupt the intramolecular hydrogen bonds between the phosphonate groups and the anthracene $\pi$-cloud. Unfortunately when tested against the same metal ions listed in figure 4 , no fluorescence enhancements were observed suggesting that the phosphonate - anthracene $\pi$-cloud interaction must be relatively strong.

\section{Conclusion}

We have presented a new class of fluorescent sensors whose response to $\mathrm{pH}$ varies considerably depending on both the number of receptors attached and the nature of the fluorophore. The reason for the unusual $\mathrm{pH}$ profile for these compounds has been attributed to a phosphonate - fluorophore $\pi$-cloud hydrogen bonding interaction that quenches fluorescence. To the best of our knowledge, this is the first reported example of such an effect with phosphonates on anthracene. In the case of compound 3 this attraction can be broken at very low $\mathrm{pH}$ 's when all the phosphonate oxyanions 
are protonated. In addition, compound $\mathbf{1}$ showed good selectivity for $\mathrm{Cu}^{2+}$ ions in water at $\mathrm{pH} 7.4$ and its sensitivity was determined to be in the physiological range.

\section{References}

1. British National Formulary (2005) Royal Pharmaceutical Society of Great Britain. 49:383

2. (a) Kiss, T.; Balla J.; Nagy, G.; Kozlowski, H.; Kowalik J.; Complexes of aminophosphonates. I. Transition metal complexes of aminophosphonic acid analogues of alanine, $\beta$-alanine, phenylalanine and tyrosine. Inorg. Chim. Acta., 1987, 138, 2 (b) Kiss, T.; Farkas, E.; Kozlowski, H.; Complexes of aminophosphonates. II. Transition metal complexes of aminophosphonic acid analogues of aspartic acid and glutamic acid. Inorg. Chim. Acta. 1989, 155, 281 (c) Matczak-Jon, E.; Kurzak, B.; Sawka-Dobrowolska, W.; Kafarski, P.; Lejczak, B.; Zinc(II) complexes of phosphonic acid analogues of glutamic acid. J. Chem. Soc. Dalton Trans. 1996, 3455 (d) Matczak-Jon, E.; Kurzak, B.; Sawka-Dobrowolska,W.; Lejczak, B,; Kafarski, P.; Zinc(II) complexes of phosphonic acid analogues of aspartic acid and asparagine. J Chem. Soc. Dalton Trans. 1998, 161 (e) Gumienna-Kontecka, E.; Jezierska, J,; Lecouvey, M,; Leroux, Y.; Kozlowski, H.; Bisphosphonate chelating agents Coordination ability of 1-phenyl-1-hydroxymethylene bisphosphonate towards $\mathrm{Cu}^{2+}$ ions. $J$. Inorg. Biochem., 2002, 89, 13 (f) Kubicek,V.; Vojtı'sek, P.; Rudovsky, J.; Hermann, P.; Lukes, I.; Complexes of divalent transition metal ions with bis 
(aminomethyl) phosphinic acid in aqueous solution and in the solid state. Dalton Trans. 2003, 3927.

3. Gumienna-Kontecka, E.; Galezowska, J.; Drag, M.; Latajka, R.; Kafarski, P.; Kozlowski, H.; Coordination abilities of substituted beta-aminophosphonates towards $\mathrm{Cu}^{2+}$ and $\mathrm{Zn}^{2+}$ ions. Inorganica. Chimica. Acta., 2004, 357, 1632.

4. Kamila, S.; Callan, J.F.; Mulrooney, R.C.; Middleton, M.; A novel fluorescent chemosensor for $\mathrm{Cu}(\mathrm{II})$ in aqueous solution based on a $\beta$ aminobisphosphonate receptor. Tetrahedron Lett. 2007, 48, 7756.

5. (a) Tsien, R.Y.; Intracellular signal transduction in four dimensions from molecular design to physiology. Am. J. Physiol. 1992, 26, 723 (b) Bissell, R.A.; de Silva, A.P.; Gunaratne, H.Q.N.; Lynch, P.L.M.; Maguire, G.E.M.; McCoy, C.P.; Sandanayake, K.R.A.S.; Fluorescent PET (photoinduced electron transfer) sensors. Top. Curr. Chem. 1993, 168, 233 (c) Czarnik, A.W.; Fluorescent chemosensors for metal and non-metal ions in aqueous solution based on the CHEF paradigm. Adv. Supramol. Chem. 1993, 3, 131 (d) Czarnik, A.W.; Chemical communication in water using fluorescent chemosensors. Acc. Chem. Res. 1994, 27, 302 (e) Fabbrizzi, L.; Poggi, A.; Sensors and switches from supramolecular chemistry. Chem. Soc. Rev. 1995, 24, 197 (f) de Silva, A.P.; Gunaratne, H.Q.N.; Gunnlaugsson, T.; Huxley, A.J.M.; McCoy, C.P.; Rademacher, J.T.; Rice, T.E.; Signalling Recognition Events with Fluorescent Sensors and Switches. Chem. Rev. 1997, 97, 1515 (g) Fabbrizzi, L.; Licchelli, M.; Pallavicini, P.; Transition Metals as Switches. Acc. Chem. Res. 1999, 32, 846 (h) Fabbrizzi, L.; The design of luminescent sensors for anions and ionisable analytes. Coord. Chem. Rev. 2000, 205, 1 (i) Kojima, H.; Nagano, T.; Fluorescent Indicators for Nitric Oxide. Adv. Mater. 
2000, 12: 763 (j) Rurack, K.; Resch-Genger, U.; Rigidization, preorientation and electronic decoupling - the magic triangle for the design of highly efficient fluorescent sensors and switches. Chem. Soc. Rev. 2002 31, 116 (k) de Silvia, A.P.; McClean, G.D.; Moody, T.S.; Weir, S.M. In Handbook of Photochemistry and Photobiology, Ed Nalwa HS. American Scientific Publishers, Stevenson Ranch, CA: 2003 (1) Martínez-Máñez, R.; Sancenón, F.; Fluorogenic and Chromogenic Chemosensors and Reagents for Anions. Chem. Rev. 2003, 103: 4419 (m) Callan, J.F., de Silvia, A.P., Magri, D.C. (2005) Luminescent sensors and switches in the early 21st century. Tetrahedron, 2005, 61, 8551.

6. Surrey, A.R. Named Reactions in Organic Synthesis. Academic Press Inc New York and London., 1961.

7. Callan, J.F.; de Silva, A.P.; McClenaghan, N.D.; Switching between molecular switch types by module rearrangement: $\mathrm{Ca}^{2+}$-enabled, $\mathrm{H}^{+}$-driven Off-On-Off, $\mathrm{H}^{+}$-driven YES and PASS 0 as well as $\mathrm{H}^{+}, \mathrm{Ca}^{2+}$-driven AND logic operations. Chem. Commun. 2004, 2048.

8. Magri, D.C.; Callan, J.F.; de Silva, A.P., Fox, D.P.; McClenaghan, N.D., Sandanayake, K.R.A.S.; The Anthracen-9-ylmethyloxy Unit: An Underperforming Motif Within the Fluorescent PET (Photoinduced Electron Transfer) Sensing Framework. J. Fluoresc. 2005, 15, 769.

9. (a) de Silva, A.P.; Gunaratne, H.Q.N.; Fluorescent PET (photoinduced electron transfer) sensors selective for submicromolar calcium with quantitatively predictable spectral and ion-binding properties. J. Chem. Soc. Chem. Commun. 1990, 14 (b) de Silva, A.P.; Gunaratne, H.Q.N.; Lynch, P.L.M.; Luminescence and charge transfer.4. On-off fluorescent PET 
(photoinduced electron transfer) sensors with pyridine receptors-1,3-diaryl-5pyridyl-4,5-dihydropyrazoles. J. Chem. Soc. Perkin. Trans. 1995, 2, 685.

10. Eaton, D.F.; Reference materials for fluorescence measurement. Pure Appl. Chem. 1988, 60, 1107.

11. Rurack, K.; Flipping the light switch 'ON' - the design of sensor molecules that show cation-induced fluorescence enhancement with heavy and transition metal ions. Spectrochim. Acta. A. 2001, 57, 2161

12. Xie, H.Y.; Liang, J.G.; Zhang, Z.L.; Liu, Y.; He, Z.K.; Pang, D.W. Luminescent $\mathrm{CdSe}-\mathrm{ZnS}$ quantum dots as selective $\mathrm{Cu}^{2+}$ probe. Spectrochimica. Acta. A. 2004, 60, 2527.

13. Gunnlaugsson, T.; Davis, A.P.; Hussey, G.M.; Tierney, J.; Glynn, M.; Design, synthesis and photophysical studies of simple fluorescent anion PET sensors using charge neutral thiourea receptors. Org. Biomol. Chem ., 2004, 2,1856.

14. Gunnlaugsson, T.; Leonard, J.P.; Sénéchal, K.; Harte, A.J.; Eu(III)-cyclenphen conjugate as a luminescent copper sensor: the formation of mixed polymetallic macrocyclic complexes in water. Chem. Commun. 2004, 782.

15. Gunnlaugsson, T.; Davis, A.P.; O’Brien, J.E.; Glynn, M.; Synthesis and photophysical evaluations of charge neutral thiourea or urea based fluorescent PET sensors for bis-carboxylates and pyrophosphate. Org Biomol Chem, 2005, 3,48 .

\section{Acknowledgements}

The authors would like to thank RGU and the Leverhulme Trust UK for financial support and Professor A.P. de Silva and Dr Bridgeen $\mathrm{M}^{\mathrm{c}}$ Caughan for helpful 
discussions. We also thank the EPSRC national Mass Spectrometry service for the high resolution spectra. 


\section{Tables}

Table 1: Photophysical properties of 1-4 and 11.

\begin{tabular}{|c|c|c|c|c|c|c|c|}
\hline Property & $\begin{array}{c}\lambda_{\text {MAX }} \\
\text { ABS }\end{array}$ & $\begin{array}{c}\lambda_{\text {MAX }} \\
\text { EM }\end{array}$ & $\begin{array}{c}\varepsilon_{\text {MAX }} \\
\mathrm{mol}^{-1} \mathrm{dm}^{3} \\
\mathrm{~cm}^{-1}\end{array}$ & $\begin{array}{c}\text { pKa } \\
\text { (Amino) }\end{array}$ & $\begin{array}{c}\text { pKa } \\
(\text { Phos- } \\
\text { phate) }\end{array}$ & $\Phi_{\text {FLU }}{ }^{\mathrm{a}}$ & $\log \beta$ \\
\hline 1 & 369 & 422 & 7485 & 10.24 & - & 0.22 & - \\
\hline 2 & 368 & 421 & 9259 & 9.43 & - & 0.16 & - \\
\hline 3 & 367 & 426 & 6601 & 8.34 & $2.80,5.99$ & 0.09 & - \\
\hline 4 & 368 & 428 & 8212 & 8.34 & - & 0.12 & - \\
\hline 11 & 283 & 333 & 5610 & 9.91 & - & 0.08 & - \\
\hline $1+\mathrm{Cu}(\mathrm{II})$ & - & 422 & - & - & - & - & 4.72 \\
\hline $1+\mathrm{Fe}(\mathrm{II})$ & - & 421 & - & - & - & - & 5.23 \\
\hline
\end{tabular}

${ }^{\text {a }}$ Quantum yields $(\Phi)$ for 1-4 were calculated with reference to anthracene while $\mathbf{1 1}$ was calculated with reference to Tryptophan. ${ }^{11} \Phi$ for $\mathbf{1}$ and $\mathbf{3}$ were recorded in $\mathrm{H}_{2} \mathrm{O}$ at pH 7.4 while 2 and $\mathbf{4}$ were recorded in EtOH. 


\section{Figures and Diagrams}

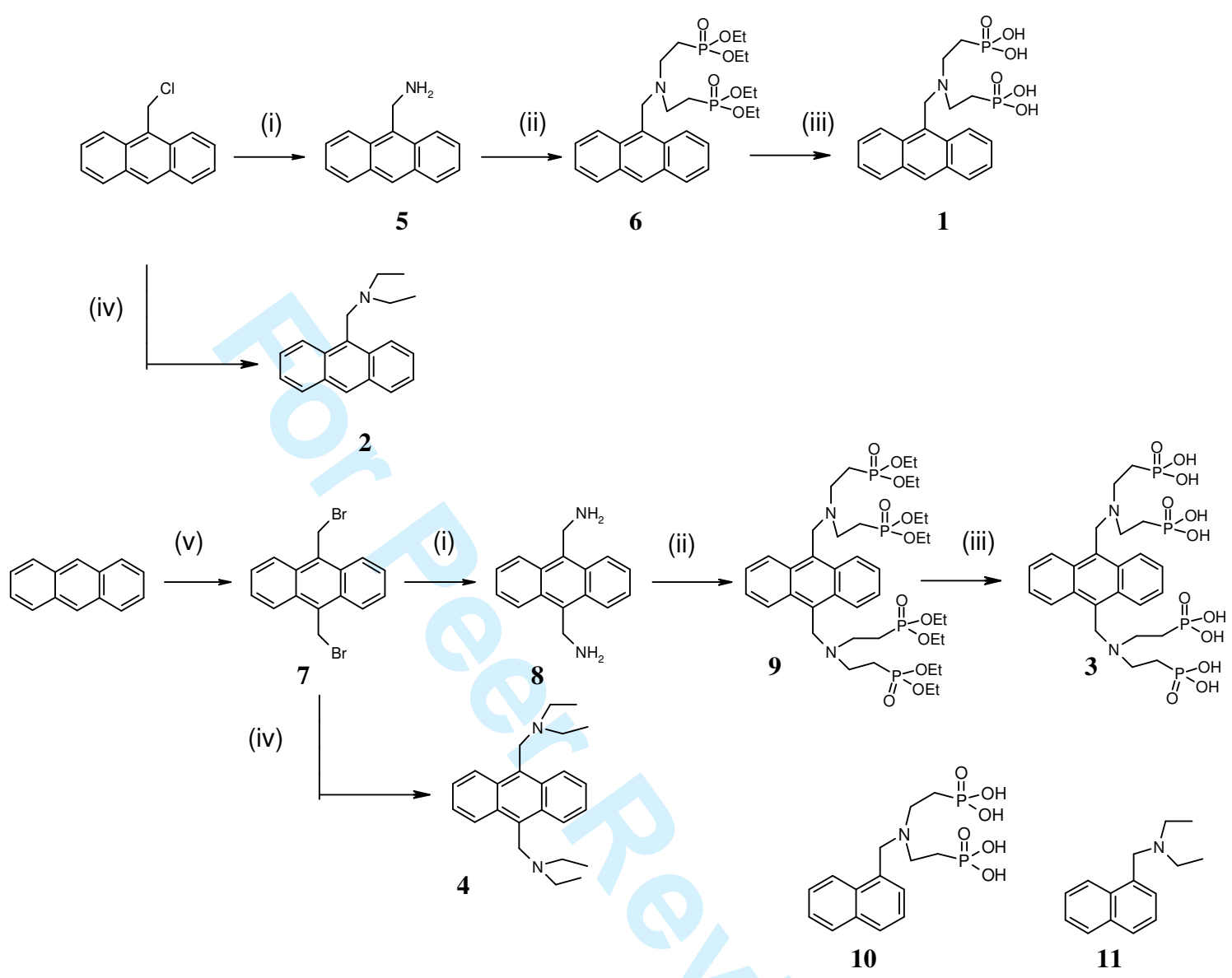

Scheme 1 Synthesis of compounds 1-4. (i) $\mathrm{C}_{6} \mathrm{H}_{12} \mathrm{~N}_{4}$, dry $\mathrm{CHCl}_{3}, 80{ }^{\circ} \mathrm{C}, 5 \mathrm{~h}$; (ii) $\mathrm{CH}_{2} \mathrm{CHPO}\left(\mathrm{OCH}_{2} \mathrm{CH}_{3}\right)_{2}$, dry $\mathrm{MeOH}, 80{ }^{\circ} \mathrm{C}, 10$ days; (iii) $\left(\mathrm{CH}_{3}\right)_{3} \mathrm{SiBr}$, dry $\mathrm{CH}_{2} \mathrm{Cl}_{2}, 28$ ${ }^{\circ} \mathrm{C}, 18 \mathrm{~h}$; (iv) $\left(\mathrm{CH}_{3} \mathrm{CH}_{2}\right)_{2} \mathrm{NH}$, DIPEA, dry $\mathrm{C}_{4} \mathrm{H}_{8} \mathrm{O}_{2}, 100{ }^{\circ} \mathrm{C}, 18 \mathrm{~h}$ (v) $\mathrm{HBr}, \mathrm{CH}_{3} \mathrm{COOH}$, $\mathrm{CH}_{3}\left(\mathrm{CH}_{2}\right)_{13} \mathrm{~N}(\mathrm{Br})\left(\mathrm{CH}_{3}\right)_{3}, \mathrm{C}_{3} \mathrm{H}_{6} \mathrm{O}_{3}, 100{ }^{\circ} \mathrm{C} 18 \mathrm{~h}$ 
Figure 1. Plot of fluorescent intensity against $\mathrm{pH}$ for $\mathbf{1}(\mathbf{\Delta})$ and $\mathbf{2}(\diamond)$. [1] $=4.40 \times 10^{-}$ ${ }^{6} \mathrm{M},[2]=1.88 \times 10^{-6} \mathrm{M}, \lambda_{\mathrm{ex}}=370 \mathrm{~nm}$. 


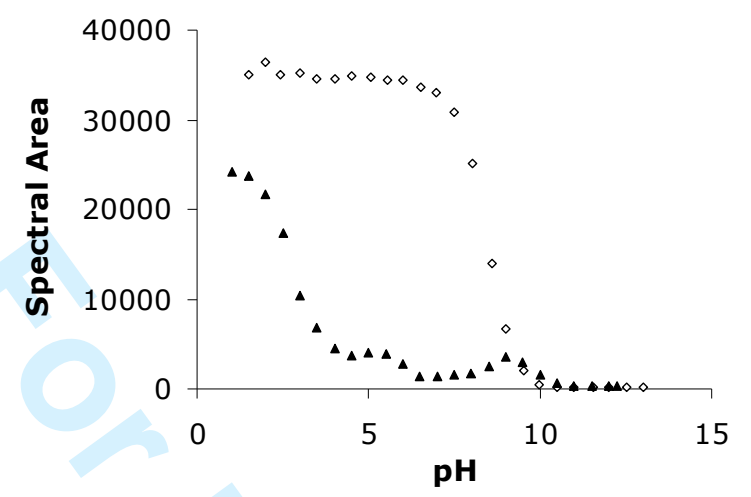

Figure 2 Plot of fluorescent intensity against $\mathrm{pH}$ for $\mathbf{3}(\boldsymbol{\Delta})$ and $\mathbf{4}(\diamond)$. [3] $=2.25 \times 10^{-}$ ${ }^{6} \mathrm{M},[4]=2.87 \times 10^{-6} \mathrm{M}, \lambda_{\mathrm{ex}}=370 \mathrm{~nm}$. 
1

2

3

4

5

6

7

8

9

10

12

13

14

15

16

17

18

19

20

21

22

23

24

25

26

27

28

29

30

31

32

33

34

35

36

37

38

39

40

41

42

43

44

45

46

47

48

49

50

51

52

53

54

55

56

57

58

59

60

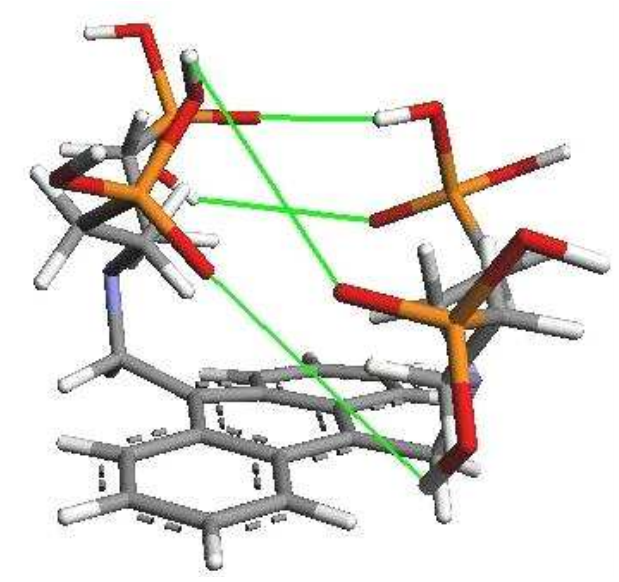

Figure 3 Illustration of potential intramolecular H-bonding between phosphonate groups on one side of $\mathbf{3}$ at low $\mathrm{pH}$. 


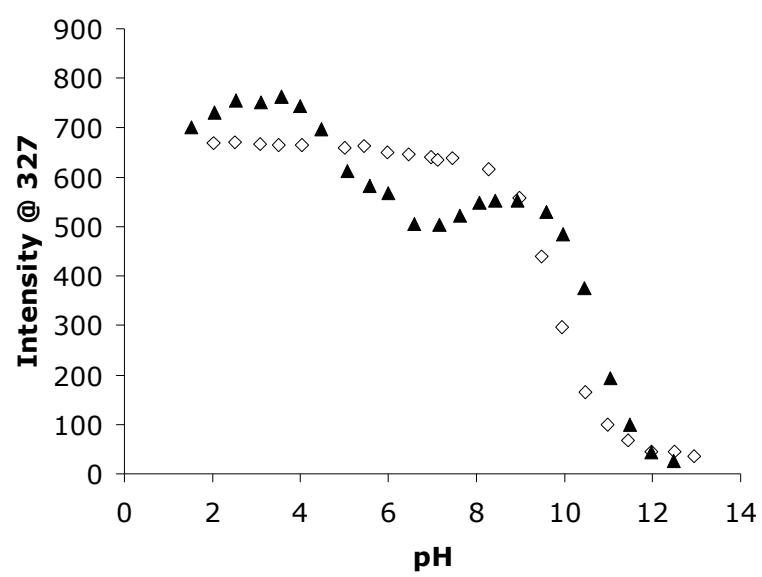

Figure 4 Plot of fluorescent intensity against $\mathrm{pH}$ for $\mathbf{1 0}(\boldsymbol{\Delta})$ and $\mathbf{1 1}(\diamond)$. [10] $=8.57 \mathrm{x}$ $10^{-7} \mathrm{M},[11]=3.8 \times 10^{-7} \mathrm{M}, \lambda_{\text {ex }}=283 \mathrm{~nm}$. 


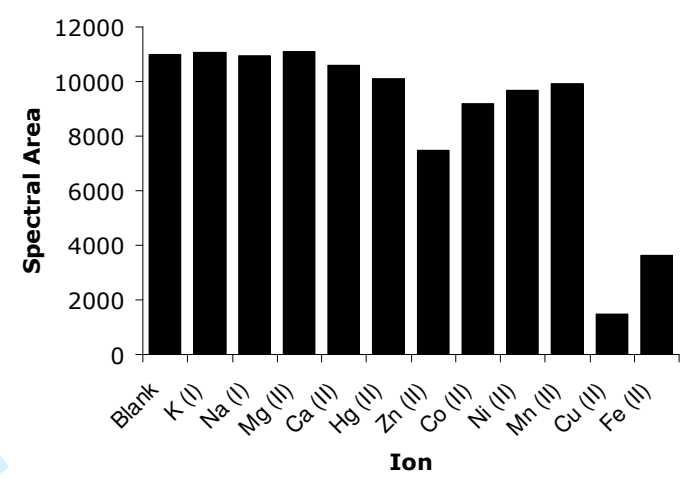

Figure 5 Selectivity Data for sensor 1 against a range of common metal ions as their chloride salts in 0.01 M HEPES buffer at $\mathrm{pH} 7.4$. [1] $=1.6 \times 10^{-7} \mathrm{M}$, [metal ion $]=1 \mathrm{x}$ $10^{-4} \mathrm{M}, \lambda_{\mathrm{ex}}=370 \mathrm{~nm}$. 

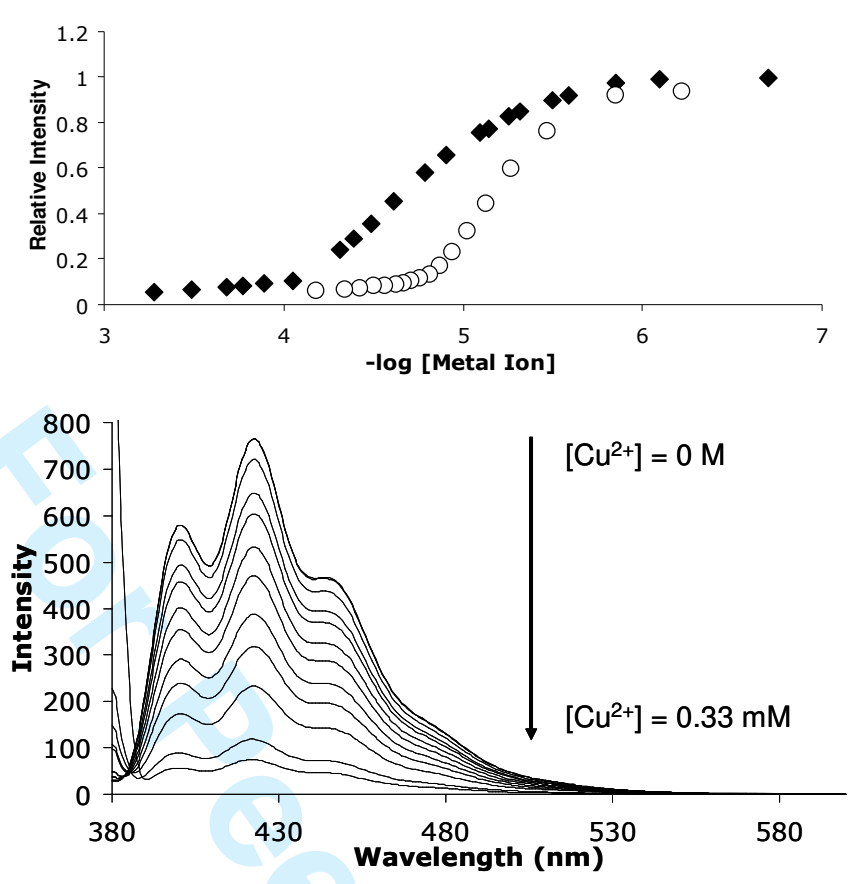

Figure 6 (a) Plot of relative intensity of $\mathbf{1}$ against $-\log$ [metal ion] for $\mathrm{Cu}$ (II) ( $\bullet$ ) and $\mathrm{Fe}$ (II) (o) as their chloride salts in 0.01 M HEPES buffer at pH 7.4. (b) Effect of $\mathrm{Cu}^{2+}$ ion concentration on the fluorescent intensity of $\mathbf{1}$. $[\mathbf{1}]=1.6 \times 10^{-7} \mathrm{M}, \lambda_{\mathrm{ex}}=370 \mathrm{~nm}$. 


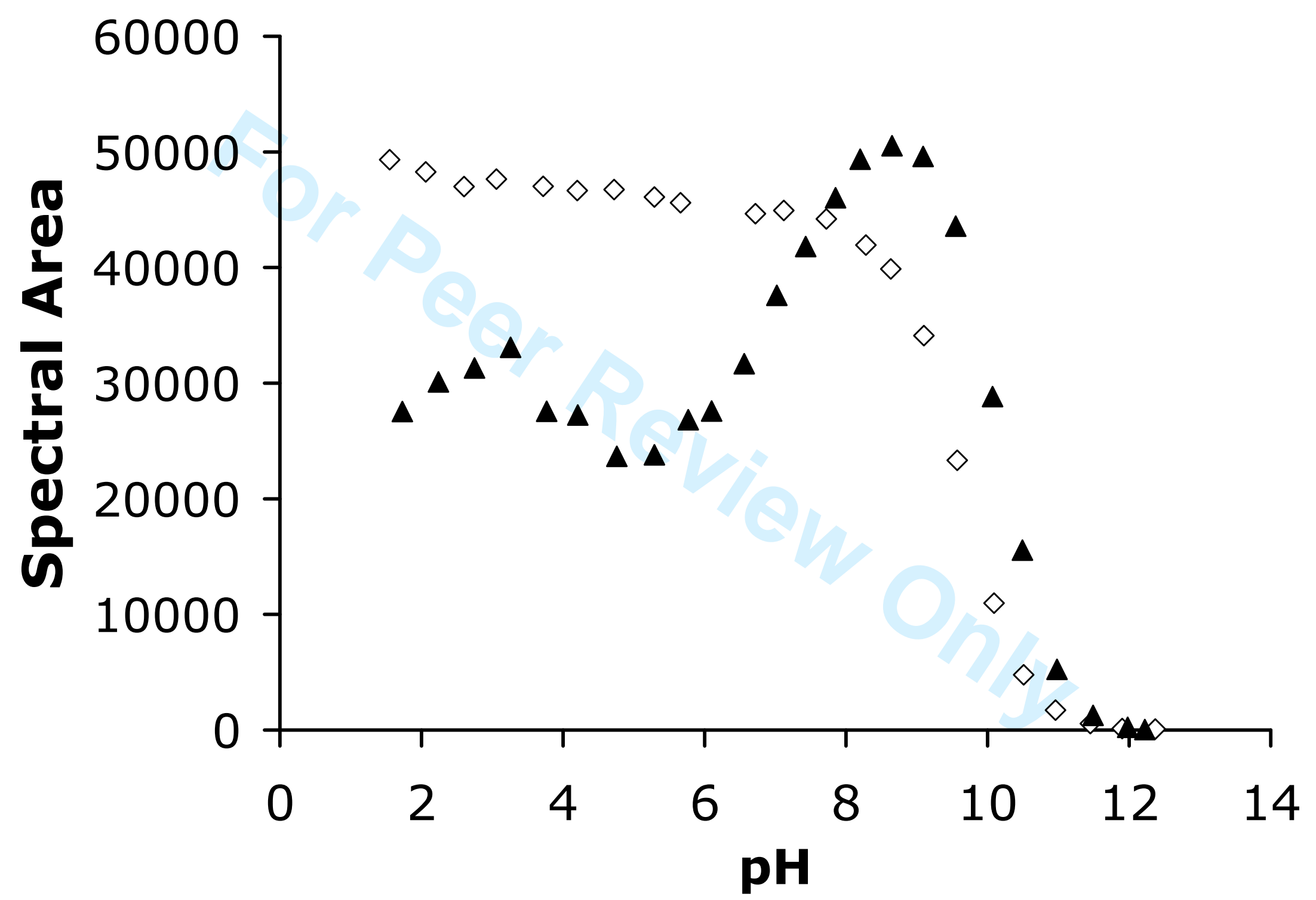

URL: http:/mc.manuscriptcentral.com/tandf/gsch Email: suprachem@mail.cm.utexas.edu 


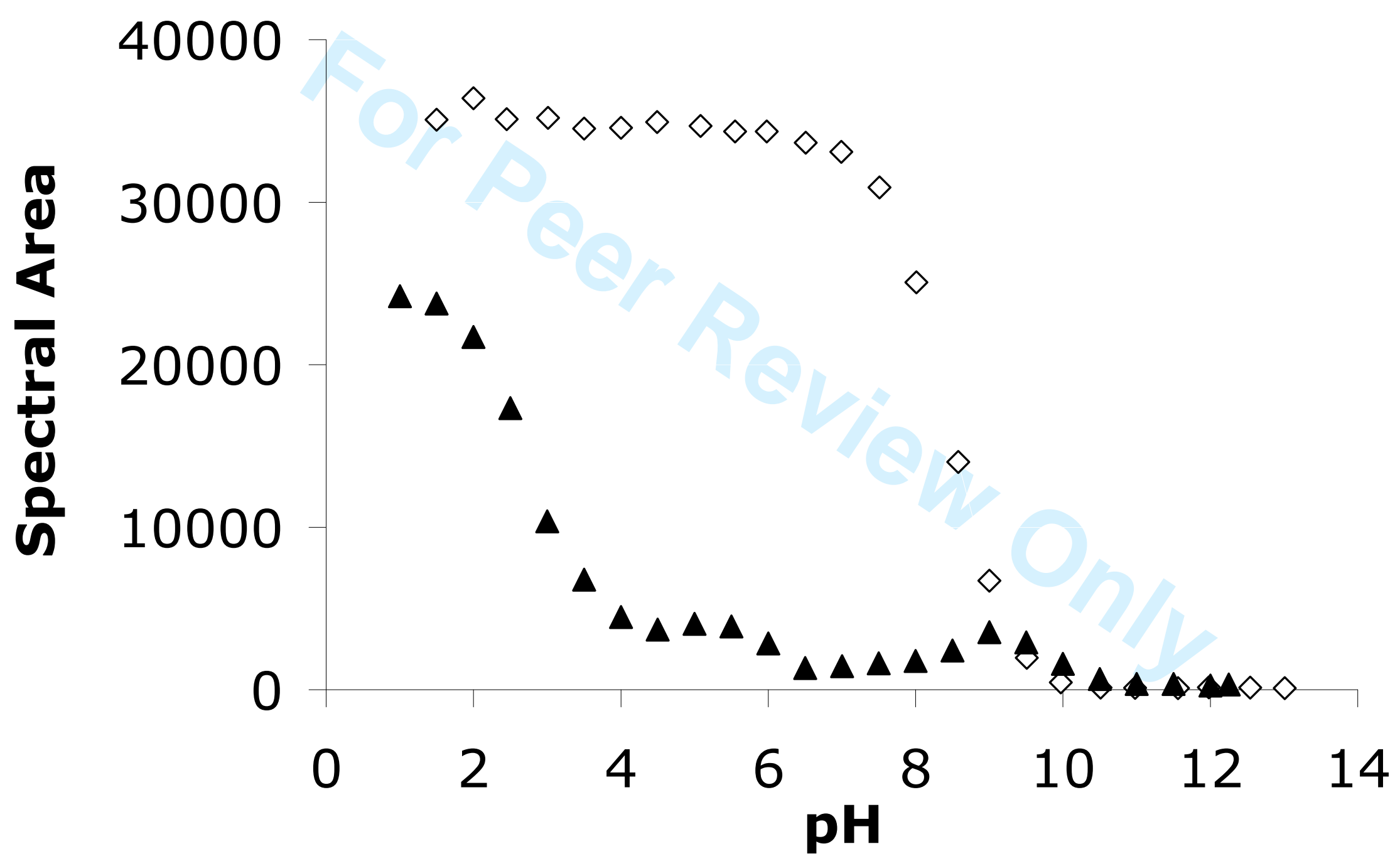

URL: http:/mc.manuscriptcentral.com/tandf/gsch Email: suprachem@mail.cm.utexas.edu 


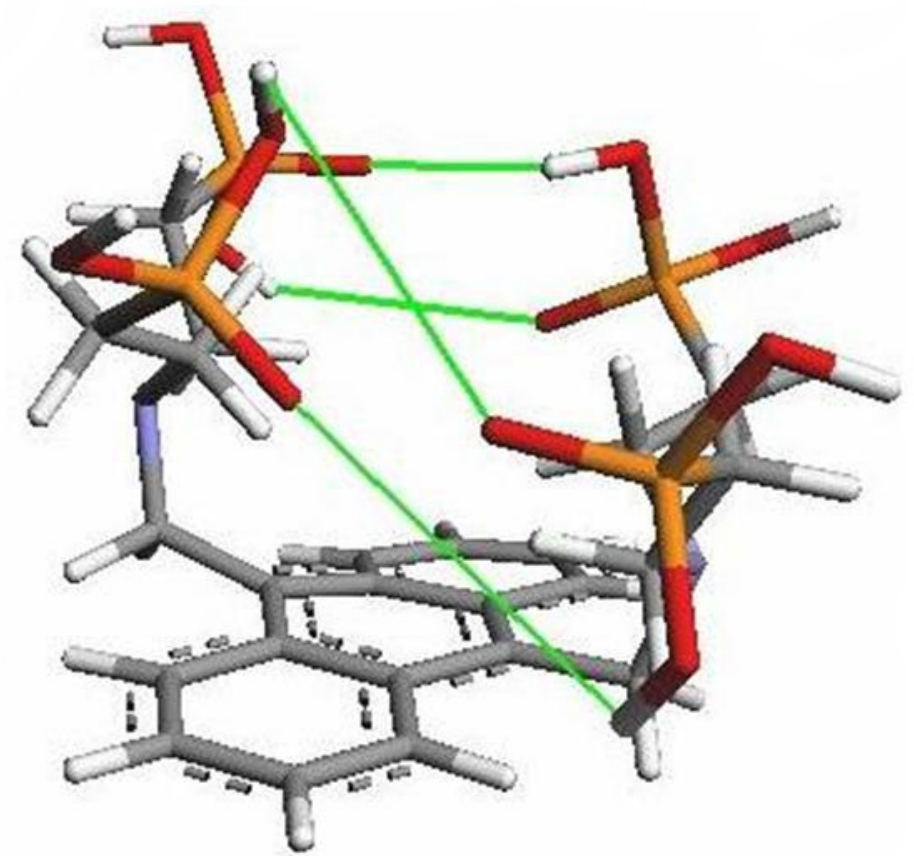




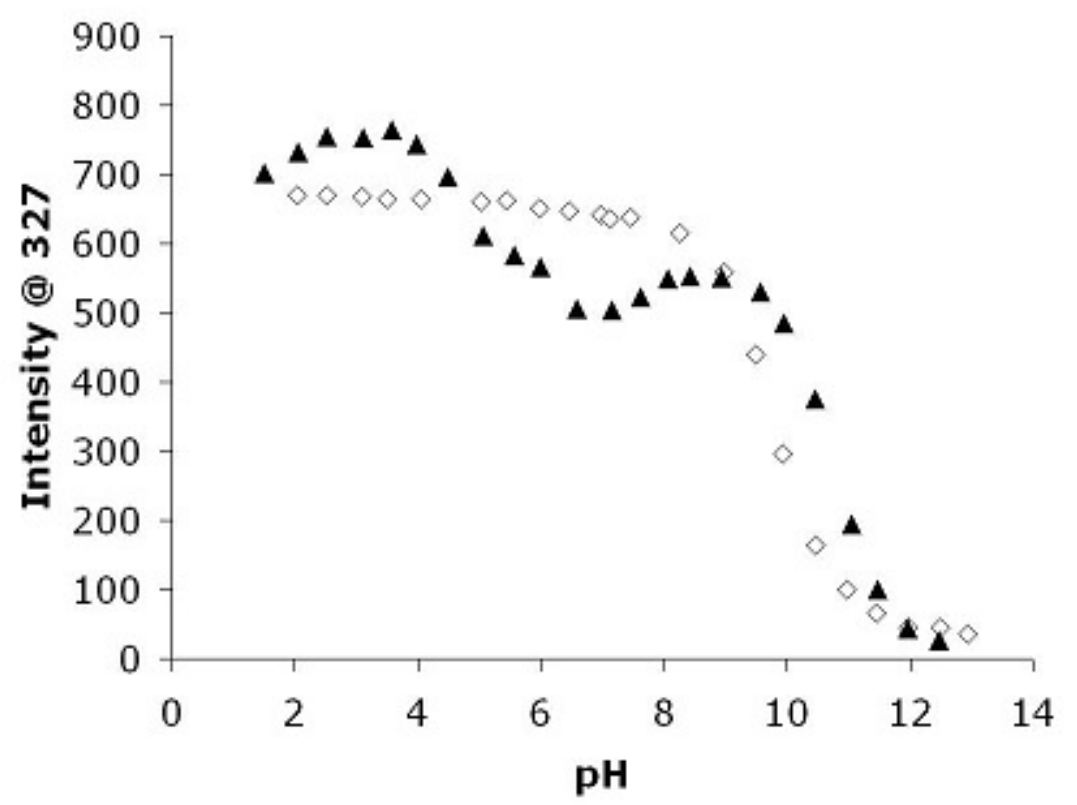




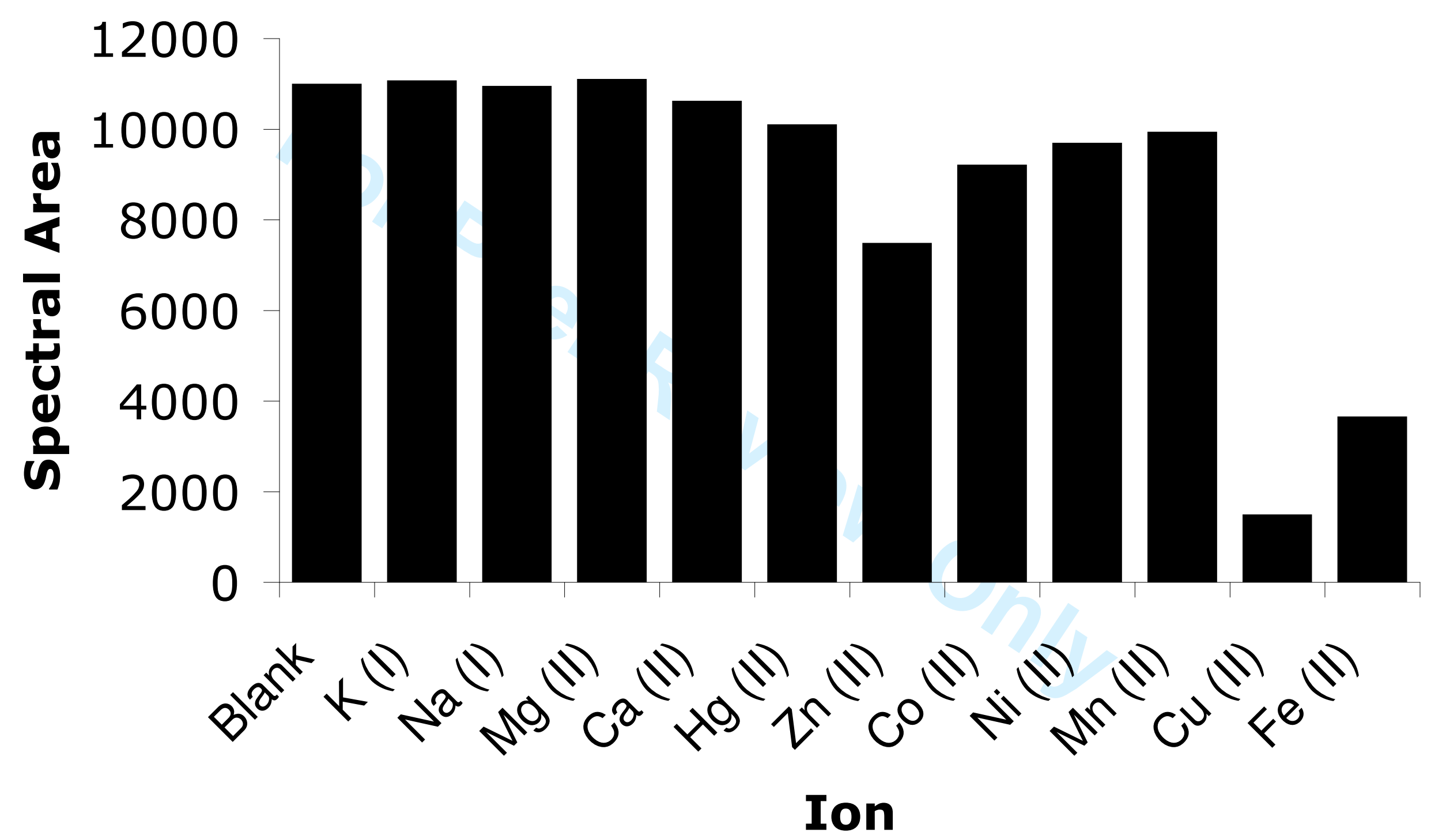

URL: http:/mc.manuscriptcentral.com/tandf/gsch Email: suprachem@mail.cm.utexas.edu 

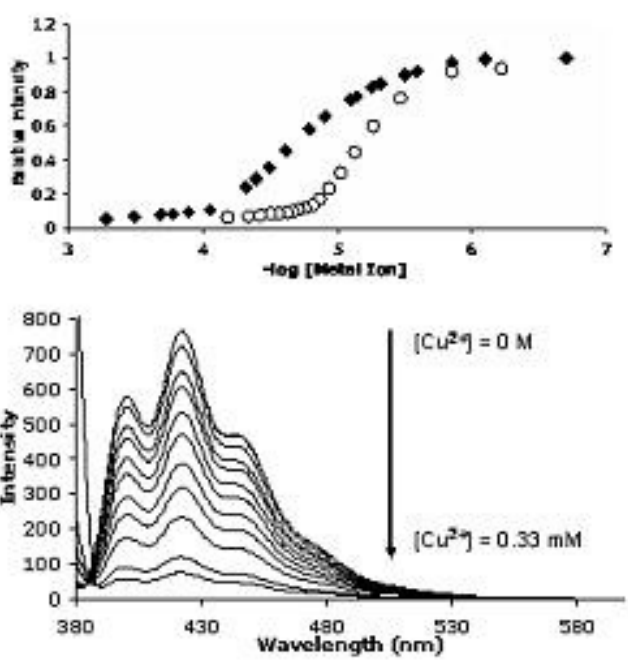